\title{
Dispatches from the editor: highlights of the September 2018 issue
}

Welcome to the September issue of the Journal of the Royal Army Medical Corps, containing 18 original submissions covering the breadth and depth of current military medicine. ${ }^{1-18}$ Transfusion support is a critical component of modern combat casualty care, and we lead this issue with an article that focuses on the potential utility of blood salvage technology and autotransfusion after combat injury. ${ }^{1}$ Lewis et $a l^{4}$ have published their review of the use of opioid analgesia in Afghanistan, finding it had been used in 5801 casualties with a very low complication rate of $0.24 \%$. The article by Carter and Gay ${ }^{5}$ highlights the continued importance of focused assessment with sonography in trauma in aiding decision-making in the austere environment where access to CT may still be limited.

We have three articles from the Academic Department of Military Mental Health based at King's College London. $^{10} 1416$ Harden and Murphy ${ }^{10}$ identify the risk factors of suicidal ideation in a population of UK military veterans seeking support for mental health difficulties. Thandi et $a l^{14}$ review the caregiver burden in spouses and partners providing informal care to wounded, injured or sick military personnel. Gribble et al ${ }^{16}$ review the hazardous alcohol consumption among spouses or partners of military service personnel. These papers are complimented by Godier and Fossey's ${ }^{13}$ review of sexual violence and harassment in the UK Armed Forces.

\footnotetext{
${ }^{1}$ Academic Department of Military Surgery and Trauma, Royal Centre for Defence Medicine, Birmingham, UK ${ }^{2}$ Division of Plastic, Maxillofacial, and Oral Surgery, Duke University Hospital, Durham, USA

Correspondence to John Breeze, Academic Department of Military Surgery and Trauma, Royal Centre for Defence Medicine, Birmingham B15 2SQ, UK;
} editor.jramc@bmj.com
Wilkins et $a l^{15}$ have reviewed the most medically significant species of venomous snake present in Africa and Europe, before suggesting an evidence-based approach to snakebite prevention and management, and these are likely to be incorporated into the UK's Clinical Guidelines for Operations. The journal continues to publish footnotes and endpieces, reflecting our commitment to supporting pertinent articles that contribute to the history of military medicine as a whole. ${ }^{18}$ We finish with a letter to the editor coauthored with the Surgeon General, and I am grateful to General Bricknell for his continuing support of the journal. ${ }^{17}$

Funding The authors have not declared a specific grant for this research from any funding agency in the public, commercial or not-for-profit sectors.

\section{Competing interests None declared.}

Patient consent Not required.

Provenance and peer review Not commissioned; internally peer reviewed.

(C) Author(s) (or their employer(s)) 2018. No commercial re-use. See rights and permissions. Published by BMJ.

To cite Breeze J. J R Army Med Corps 2018;164:315.

Received 23 August 2018

Accepted 23 August 2018

Published Online First 6 September 2018

J R Army Med Corps 2018;164:315.

doi:10.1136/jramc-2018-001054

\section{REFERENCES}

1 Sahloul M, Bowley D, Kirkman E, et al. Blood salvage technology after combat injury. J R Army Med Corps 2018;5:316-317.

2 Guven S, Durukan AH. Terroristic sniper shot ocular injuries: military and police casualties: case series. $J R$ Army Med Corps 2018;5:318-321.

3 de Kruijff LGM, Prins M, van der Krans A, et al. Combat-related foot injuries: impact on gait and functional outcome. J R Army Med Corps 2018;5:322-327.
4 Lewis P, Wright C, Hooper C. Opioid analgesia on the battlefield: a retrospective review of data from Operation HERRICK. J R Army Med Corps 2018:5:328-331.

5 Carter NJ, Gay D. FAST in the deployed military setting. J R Army Med Corps 2018;5:332-334.

6 Lewis CT, Malein WL, Chesner I, et al. High altitude arterialised capillary earlobe blood gas measurement using the Abbott i-STAT. J R Army Med Corps 2018:335-337.

7 Roscoe D, Roberts AJ, Hulse D, et al. Effects of anterior compartment fasciotomy on intramuscular compartment pressure in patients with chronic exertional compartment syndrome. J R Army Med Corps 2018;5:338-342.

8 Aydin A, Bilge S, Eryilmaz M. Safest light in a combat area while performing intravenous access in the dark. J R Army Med Corps 2018;5.

9 Bonanno DR, Munteanu SE, Murley GS, et al. Risk factors for lower limb injuries during initial naval training: a prospective study. J R Army Med Corps 2018;5:347-351.

10 Harden L, Murphy D. Risk factors of suicidal ideation in a population of UK military veterans seeking support for mental health difficulties. J R Army Med Corps 2018;5.

11 Pujji 0 , Jeffery SLA. Safe burn excision prior to military repatriation: an achievable goal? J R Army Med Corps 2018:358-359.

12 Hammond D, Breeze J, Evriviades D. The reconstructive trauma surgery interface fellowship and its applicability to military and civilian trainees. J R Army Med Corps 2018:5.

13 Godier LR, Fossey M. Addressing the knowledge gap: sexual violence and harassment in the UK Armed Forces. J R Army Med Corps 2018;5.

14 Thandi G, Harden L, Cole L, et al. Systematic review of caregiver burden in spouses and partners providing informal care to wounded, injured or sick (WIS) military personnel. J R Army Med Corps 2018;5:365-369.

15 Wilkins D, Burns DS, Wilson D, et al. Snakebites in Africa and Europe: a military perspective and update for contemporary operations. J R Army Med Corps 2018:370-379.

16 Gribble R, Thandi GK, Goodwin L, et al. Hazardous alcohol consumption among spouses or partners of military service personnel: a systematic review of the literature. J R Army Med Corps 2018;5:380-388.

17 McKillop-Duffy PS, Bricknell M. Defence policy and doctrine on captured persons (CPers): further guidance. J R Army Med Corps 2018;5.

18 Davidson J. Threading the needle: when embroidery was used to treat shell-shock. J R Army Med Corps 2018;5:390-391. 